\title{
9.2 スポーツ施設
}

平成17年は，一般市民のレクリエーション利用を主目的とした 屋外施設, また, 天候に左右されない屋内スポーツ施設の建設が 多く見られ，大規模施設の建設および国体会場として利用するた めの施設整備は，例年並みに抑えられている。

屋外施設は，昨年同様，省エネルギー，環境配慮をキーワード に効率改善形投光器や光害対策形投光器を採用する施設が多く見 られる。屋内施設は, 省エネルギー, 多目的での利用に配慮して 目的に応じた点灯パターンに設定できる制御システムを採用する 施設が多く見られる。

なお，建設後20年以上を経過したスポーツ施設が増加してきて おり, 照明機器の性能向上と施設老朽化の相乗効果により, 今後, 施設リニューアルの増加が期待される.

「荻野運動公園競技場」（図9.2.1）は, 神奈川県厚木市にあり, 約 $16 \mathrm{ha}$ という広大な敷地面積の公園内にある第 2 種公認陸上競 技場である。照明設備は，コーナー 4 力所に照明塔を新設，照明 器具は, $1500 \mathrm{~W}$ 効率改善形メタルハライドランプ投光器を用い ている，投光器はすべてフードルーバ付とし，周辺環境への光漏 れに配慮している。

「向島町運動公園」(図9.2.2) は, 広島県尾道市に地域のスポー ツ振興のための多目的グラウンドとして整備された施設である。 夜間照明設備は, 効率改善形投光器 (内蔵ルーバ付) と $1500 \mathrm{~W}$ メタルハライドランプを採用している。

「豊田市運動公園ソフトボール場」（図9.2.3）は，愛知県豊田 市に市民のスポーッ・レクリエーションの拠点として豊田市が整
備した運動公園内に新設されたISF（国際ソフトボール連盟）の 国際ルールを満足するソフトボール場である，光源には $1500 \mathrm{~W}$ メタルハライドランプと250W 高圧ナトリウムランプ(混光比 $\mathrm{M}$ : $\mathrm{NH}=7: 3$ ）を採用，これを光害対策形投光器と組み合わせ 4 基の照明塔に配置している。

「佐用中学校グラウンド」（図9.2.4）は, 兵庫県作用郡佐用町 にある豊かな自然に囲まれた中学校である. 同町は, 環境省が主 催する「全国星空の街108選」に入選したのをきっかけに「きら めく星，きらめく人，きらめく町」をキーワードに「星の都づく り」を合言葉としてまちづくりに取り組んでいる.グラウンドは, 夜間開放され，1000Wメタルハライドランプ照明器具と光害対 策形投光器を用いることにより，上方向の光を下方向に制御する ことでグラウンドへの有効な光を維持し, 天体観測に配慮すると 共に省エネを図った照明を実現している.

「駒沢オリンピック公園総合運動場（第二球技場・補助競技場）」 (図9.2.5) は, 東京都世田谷区駒沢オリンピック運動公園内の 競技場である. 光源には, $1500 \mathrm{~W}$ メルハライドランプを採用, 近隣の高層住宅に配慮し, 照明器具には, 光害対策形投光器が採 用されている。

「天理大学体育学部総合体育館」(図9.2.6) は, 奈良県天理市 に天理大学体育学部の体育館として平成17年 6 月に完成した施設 で,メイン・サブアリーナ, 体操場, プール, トレーニング場な どを完備している，省エネを考慮した施設づくりが進められ, 照 明設備も目的に合わせた点灯パターンが容易に設定できる制御シ

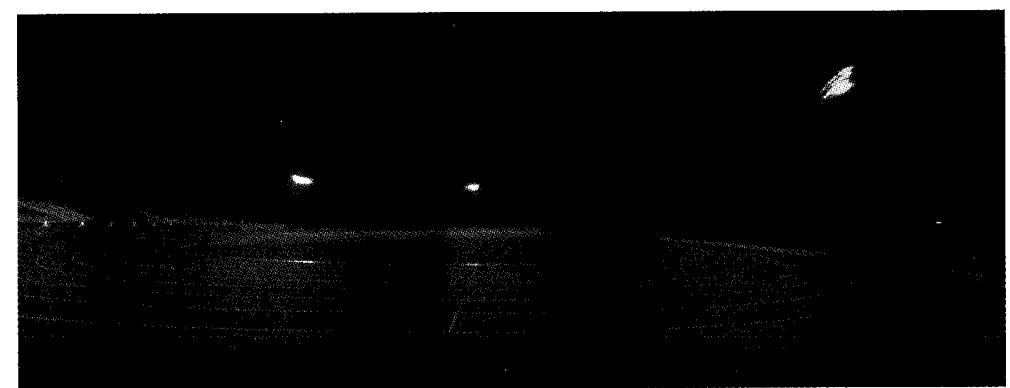

図9.2.1荻野運動公園競技場（神奈川県） ( (C)岩崎電気(侏)

1500W 高効率形メタルハライドランプ（ロングアークタイプ） $\times 156$ 灯 $1000 \mathrm{~W}$ 両口金形八ロゲン電球 $\times 12$ 灯 維持水平泊照度 : $300 \mathrm{~lx}$

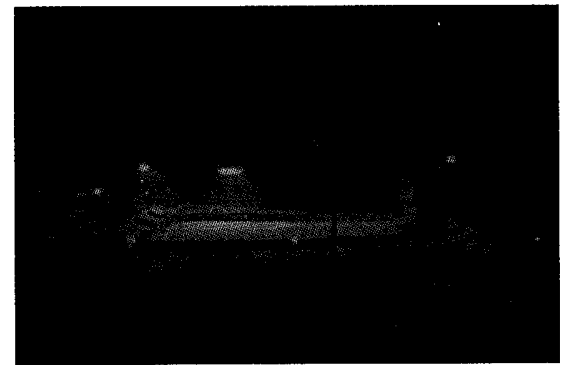

図9.2.3豊田市運動公園ソフトボール場(愛知県) (C)松下電工 $\left.\left(x_{⿰}\right)\right)$

1500W 高効率形メタルハライドランプ× 40 灯 250W 高圧ナトリウムランプ×20灯 維持水平面照度：内野 $600 \mathrm{~lx} \cdot$ 外野 $300 \mathrm{~lx}$

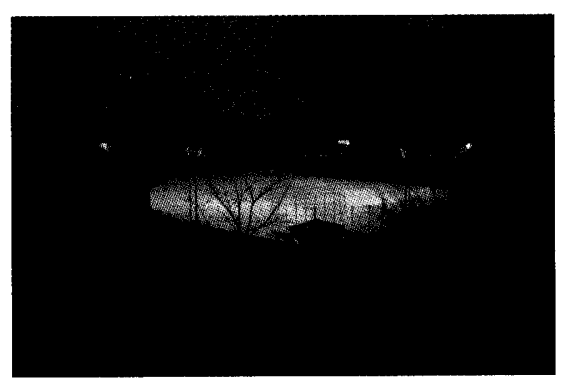

図9.2.4 佐用中学校グラウンド（兵庫県） (C)松下電工(侏)

1000W 高効率形メタルハライドランプ×70灯 維持水平面照度 : $250 \mathrm{~lx}$

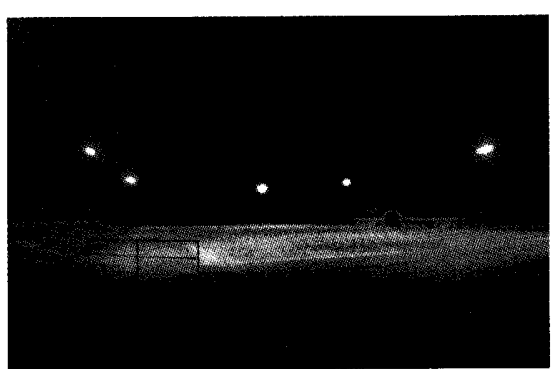

図9.2.2 向島町運動公園 (広島県) (C)岩崎電気(俶)

1500W 高効率形メタルハライドランプ×63灯

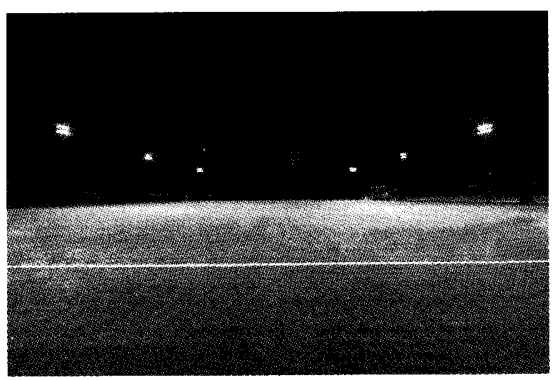

図9.2.5 駒沢オリンピック公園総合運動場（第 二球技場・補助競技場) (東京都) (C)岩崎電気(侏)

$1500 \mathrm{~W}$ 高効率形メタルハライドランプ×120灯 維持水平面照度：全体 $300 \mathrm{~lx}$ 


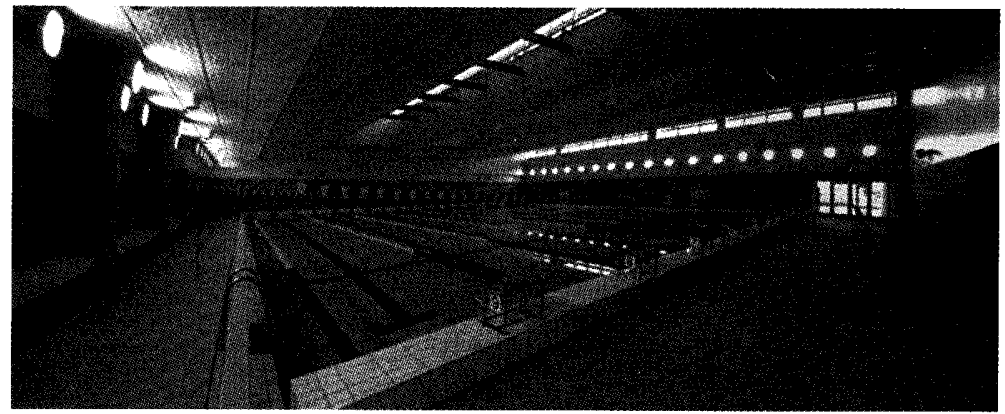

図9.2.6 天理大学体育学部総合体育館（奈良県） (@岩崎電気(侏)

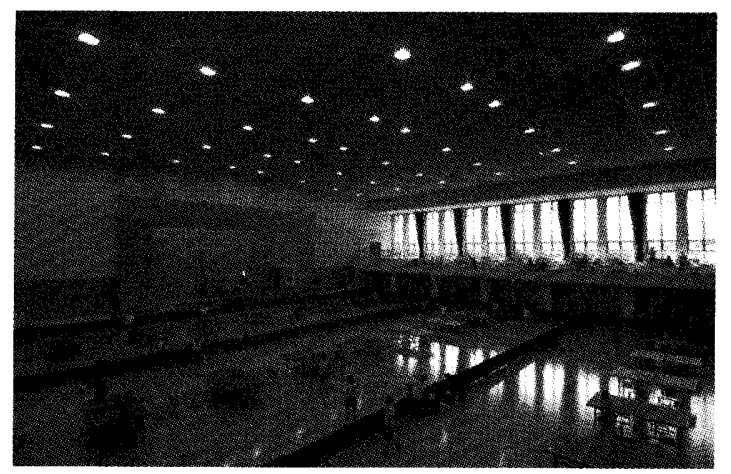

図9.2.8 大内町総合体育館（秋田県） (@岩崎電気(侏)

メインアリーナ：400W 高効率形メタルハライドランプ×140灯 サブアリーナ：400W 高効率形メタルハライドランプ×38灯

\section{ステムが採用されている.}

「しもきた克雪ドーム」(図9.2.7) は，冬季深い雪に閉ざされ るこの地域において, 季節や天候に左右されずにスポーツを楽し むことのできる全天候施設として青森県むつ市に建設された。 ドーム屋根は，ガラス繊維を配合したテフロン加工仕上げとなっ ており，昼は昼光を透過，夜間は照明の光でぼんやりと明るくな り, むつ市の夜間のシンボルとなっている.この施設は, 各種ス ポーツ競技のほか, 各種イベントにも利用できる。照明は, 1000Wメタルハライドランプ投光器を採用, これを使用用途に より点灯できるような照明制御システムを採用している.

「大内町総合体育館」（図9.2.8）は, 床面積 $1710 \mathrm{~m}^{2}$ のメイン アリーナのほか, サブアリーナ, トレーニングルーム, ミーティ ングルームを有し，秋田県由利本庄市に建設された。本施設は， 平成19年秋田国体の柔剣道場会場として使用される予定である。 メイン・サブアリーナともメンテナンスを考慮して, 電動昇降装 置付の照明器具が採用され, 天井と照明器具が調和した仕上がり

近年の街路照明を検討するときのキーワードは, 省エネルギー, 高効率, 安全安心, 防犯, 光害が挙げられる. どのキーワードも 定着した感があり外せないものとなっている.

照明器具においては, 光害対策をされたもので設置筒所に応じ た光学特性をもち合わせるものが採用されるケースがある. 交差

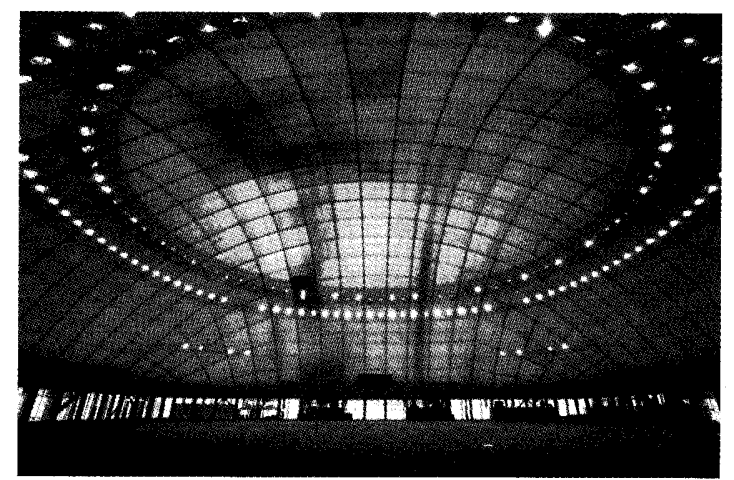

図9.2.7 しもきた克雪ドーム（青森県） (C東芝ライテック(俶)

$1000 \mathrm{~W}$ 高効率形メタルハライドランプ×124灯

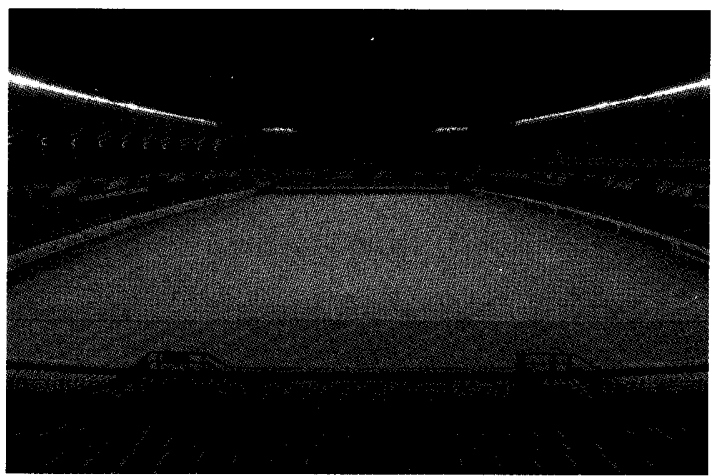

図9.2.9 フクダ電子アリーナ（千葉県総合スポーツ公園市民 球技場) (千葉県)

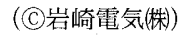

2000W 高演色形ショートアークメタルハライドランプ×144灯

1500W 高演色形ロングアークメタルハライドランプ×108灯

となっている. また, 光補償装置付の照明器具を使用し, 不意の 消灯時にも保安照明の機能を果たし，安全性にも配慮している．

「フクダ電子アリーナ (千葉市総合スポーツ公園市民球技場)」 （図9.2.9）は, 観客席18500席を有するサッカー専用スタジアム として，平成17年10月に千葉県千葉市に建設されている。本施設 は，スタンドの約 9 割がアルミハニカムパネルと鉄骨パイプを使 用した屋根で覆われ，Jリーグジェフユナイテッド千葉のホーム スタジアムとなるほか，市民も利用できる施設となっている，照 明は， $2000 \mathrm{~W}$ 高演色形ショートアークメタルハライドランプ投 光器と $1500 \mathrm{~W}$ 高演色形ロングアークメタルハライドランプ投光 器をスタンド屋根に設置, Jリーグ公式戦が開催可能な設備と なっている．また，瞬時再点灯形器具および保安灯の設置により 安全性にも配慮している。

（立場川 一広・岩崎電気(侏)）

路

点の四隅に設置し，交差点中央を重点的に明るくするもの，従来 よりも設置間隔を広くしても均斉度が確保できるものなどであ る。

ランプについて，高压ナトリウムランプが一般的であるが，都 市部, 駅前広場や歩行者の利用を考慮した場合, 白色系のセラミッ 